\section{Survival of a Surrogate Virus on N95 Respirator Material}

To the Editor-Protecting healthcare providers from occupational respiratory disease is crucial for public health preparedness; outbreaks of severe acute respiratory syndrome and influenza have shown that transmission from patient to healthcare worker is an occupational hazard. ${ }^{1,2}$ While N95 respirators are vital for protection against occupational respiratory infection, potential shortages in outbreak situations are a serious preparedness issue. ${ }^{3}$ Reuse of respirators is a potential solution; however, contaminated respirators are potential vehicles for pathogen spread during handling and reuse. Methods for respirator decontamination have been explored, but developing effective decontamination protocols requires data on virus survival on respirator surfaces to determine the frequency and efficacy of decontamination required to reduce the risks of reuse. The goal of this research is to determine the inactivation rates of virus on the surface of N95 respirators at ambient temperature and humidity levels using bacteriophage $\Phi 6$, an enveloped virus and potential surrogate for human respiratory viruses.

Bacteriophage and host were kindly provided by Leonard Mindich, University of Medicine and Dentistry, New Jersey. Virus was propagated in host Pseudomonas syringae using the soft agar propagation method. Thirty milliliters of host bacterial culture were grown for 24 hours with shaking (100 $\left.\mathrm{rpm}, 25^{\circ} \mathrm{C}\right)$. Virus stock $(2 \mathrm{~mL})$ was added and incubated with shaking for another 24 hours. This virus culture (0.5
$\mathrm{mL})$ and fresh host culture $(0.5 \mathrm{~mL})$ were added to $30 \mathrm{~mL}$ of soft agar ( $0.7 \%$ agar), dispensed into tryptic soy bottom agar plates, and incubated at $25^{\circ} \mathrm{C}$ for 24 hours. The top layer was then harvested, pooled, purified by centrifugation $(5,900$ $\mathrm{g}, 30$ minutes, $4^{\circ} \mathrm{C}$ ), and stored as stock in tryptic soy broth with $20 \%$ glycerol at $-80^{\circ} \mathrm{C}$.

Virus stock was diluted in phosphate buffered saline (PBS) to target a concentration of $10^{5}$ plaque-forming units (PFUs) in $10 \mu \mathrm{L}$. Ten microliters were placed onto six $1-\mathrm{cm}^{2}$ coupons of $\mathrm{N} 95$ respirator material (model $1860,3 \mathrm{M}$ ). Time 0 carriers were sampled immediately. For sampling, coupons were placed in tubes using sterile forceps. Two milliliters of $1.5 \%$ beef extract ( $\mathrm{pH} 7.5$ ) were added into each tube and agitated on a shaker at $60 \mathrm{rpm}$ for 20 minutes. Samples were assayed using the double agar layer plaque assay on tryptic soy agar and incubated at $25^{\circ} \mathrm{C}$ for 24 hours. For the other time points, carriers were placed into controlled humidity environments at $22^{\circ} \mathrm{C}$ and either $40 \%( \pm 2 \%)$ or $60 \%( \pm 2 \%)$ relative humidity $(\mathrm{RH})$, created by placing saturated salt solutions in sealed glass containers. Virus survival at each time point was expressed as $\log _{10}\left(N_{t} / N_{0}\right)$, where $N_{t}$ is the virus concentration (PFU/mL) at time $t$ and $N_{0}$ is the initial virus concentration $(\mathrm{PFU} / \mathrm{mL})$ in the control sample at time 0 . Data were analyzed with Excel 2007 (Microsoft) and GraphPad Prism 5 (GraphPad).

Over 24 hours, there was an $\sim 1 \log _{10}$ reduction in infectious virus at $22^{\circ} \mathrm{C}$ and $40 \% \mathrm{RH}$, while there was an $\sim 4 \log _{10}$ reduction at $22^{\circ} \mathrm{C}$ and $60 \% \mathrm{RH}$ (Figure 1). The rate of virus inactivation is significantly less at $40 \% \mathrm{RH}$ (slope = $-0.046 \pm 0.007$ ) than at $60 \% \mathrm{RH}$ (slope $=-0.20 \pm 0.006$;

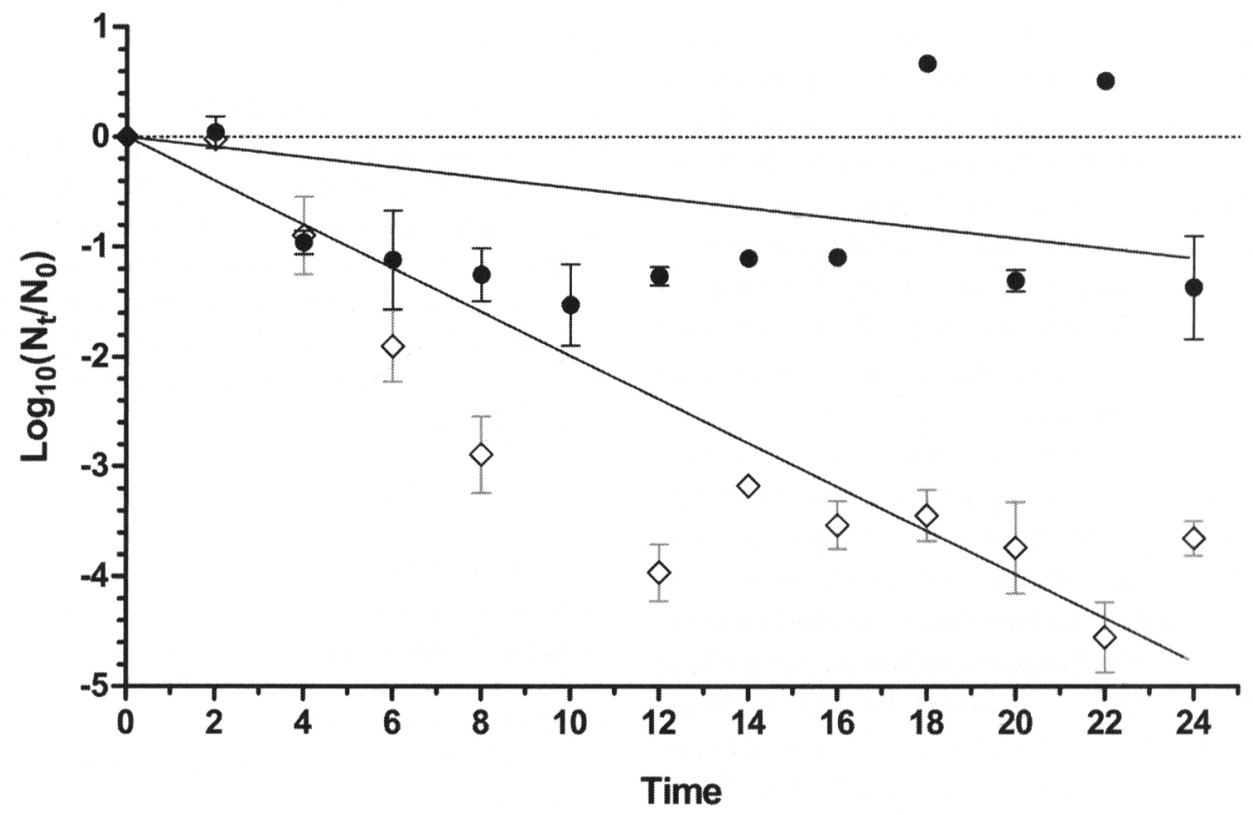

FIGURE 1. Survival of bacteriophage $\Phi 6$ over 24 hours at $22^{\circ} \mathrm{C}$ at $40 \%$ and $60 \%$ relative humidity (6 replicates per point). Circles, $40 \%$; diamonds, $60 \%$. Regression lines: solid lines, 40\%; dashed line, $60 \%$. Bars, $95 \%$ confidence interval. 
$P<.0001)$. Within the time frame of a typical patient care encounter (approximately 30 minutes), there was a $<0.02 \log _{10}$ reduction in virus at $40 \% \mathrm{RH}$, while there was a $<0.1 \log _{10}$ reduction at $60 \% \mathrm{RH}$. Achieving a $4 \log$ reduction of infectious virus on a mask surface would take 87 hours at $40 \% \mathrm{RH}$ and 20 hours at $60 \% \mathrm{RH}$.

Enveloped bacteriophage $\Phi 6$ can survive on the surface of an N95 respirator longer than a single patient care encounter. High levels of virus remaining on a respirator may pose a risk of virus transfer to the wearer during handling and reuse. ${ }^{4}$ The use of a bacteriophage provides a simple, low-cost method for evaluating survival and transfer risks; bacteriophages are already used as surrogates in studies of respirator decontamination. ${ }^{5}$ Bacteriophage $\Phi 6$ was inactivated somewhat more rapidly than H1N1 influenza on N95 surfaces at $60 \% \mathrm{RH}$ (possibly as a result of the matrix used), and a similar trend of greater inactivation was observed at higher humidity levels. ${ }^{6}$ The results are similar to those found for transmissible gastroenteritis virus, a member of the coronavirus family, on respirator surfaces. ${ }^{7}$ This suggests that bacteriophage $\Phi 6$ is a potential surrogate for studies of human respiratory viruses on personal protective equipment.

The inactivation observed demonstrates that residual virus on a respirator surface is an important factor when reuse is considered. If a respirator is used over an 8- or 12-hour shift, even $90 \%$ inactivation during that time raises the possibility that that reuse over multiple patient encounters may add additional viral load to an already contaminated respirator. Therefore, decontamination of respirators is an important consideration in any reuse scenario. ${ }^{8}$ Studies of infectious virus reduction ${ }^{9}$ suggest that decontamination may be a viable option if pandemic situations or shortages make respirator reuse an alternative that needs to be considered. The design of effective respirator decontamination protocols should include the intervals at which a respirator needs to be decontaminated between uses, as well as how long a respirator should be used before discarding. Virus survival data is needed to model inactivation, decontamination, and recontamination to determine safe and effective reuse protocols. Long-term survival of respiratory viruses on the surface of N95 respirators needs to be taken into account when evaluating decontamination protocols and weighing the risks and benefits of respirator reuse for outbreak and pandemic preparedness.

\section{ACKNOWLEDGMENTS}

Financial support. This project was supported by a Georgia State University Research Initiation Grant.

Potential conflicts of interest. All authors report no conflicts of interest relevant to this article. All authors submitted the ICMJE Form for Disclosure of Potential Conflicts of Interest, and the conflicts that the editors consider relevant to this article are disclosed here.

Lisa M. Casanova, $\mathrm{PhD}^{1}{ }^{1}$ Behelhem Waka, $\mathrm{MPH}^{1}$
Affiliation: 1. School of Public Health, Georgia State University, Atlanta, Georgia.

Address correspondence to Lisa M. Casanova, $\mathrm{PhD}$, School of Public Health, PO Box 3995, Atlanta, GA 30302 (Icasanova@gsu.edu).

Presented in part: General Meeting of the American Society for Microbiology; San Francisco, California; 2012.

Infect Control Hosp Epidemiol 2013;34(12):1334-1335

(C) 2013 by The Society for Healthcare Epidemiology of America. All rights reserved. 0899-823X/2013/3412-0022\$15.00. DOI: $10.1086 / 673994$

\section{REFERENCES}

1. Wise ME, De Perio M, Halpin J, et al. Transmission of pandemic (H1N1) 2009 influenza to healthcare personnel in the United States. Clin Infect Dis2011;52(suppl 1):S198-S204.

2. Ho AS, Sung JJ, Chan-Yeung M. An outbreak of severe acute respiratory syndrome among hospital workers in a community hospital in Hong Kong. Ann Intern Med 2003;139(7):564-567.

3. Institute of Medicine of the National Academies. Reusability of Facemasks during an Influenza Pandemic: Facing the Flu. Washington, DC: National Academies Press, 2006.

4. Fisher EM, Richardson AW, Harpest SD, Hofacre KC, Shaffer RE. Reaerosolization of MS2 bacteriophage from an N95 filtering facepiece respirator by simulated coughing. Ann Occup Hyg 2012; 56(3):315-325.

5. Vo E, Rengasamy S, Shaffer R. Development of a test system to evaluate procedures for decontamination of respirators containing viral droplets. Appl Environ Microbiol 2009;75:7303-7309.

6. Coulliette A, Perry K, Edwards J, Noble-Wang J. Persistence of the 2009 pandemic influenza A (H1N1) virus on N95 respirators. Appl Environ Microbiol 2013;79(7):2148-2155.

7. Casanova L, Rutala WA, Weber DJ, Sobsey MD. Coronavirus survival on healthcare personal protective equipment. Infect Control Hosp Epidemiol 2010;31(5):560-561.

8. Viscusi DJ, Bergman MS, Eimer BC, Shaffer RE. Evaluation of five decontamination methods for filtering facepiece respirators. Ann Occup Hyg 2009;53(8):815-827.

9. Heimbuch BK, Wallace WH, Kinney $\mathrm{K}$, et al. A pandemic influenza preparedness study: use of energetic methods to decontaminate filtering facepiece respirators contaminated with $\mathrm{H} 1 \mathrm{~N} 1$ aerosols and droplets. Am J Infect Control 2011;39(1):e1-e9.

\section{Evaluation of Universal Methicillin- Resistant Staphylococcus aureus Screening Using Nasal Polymerase Chain Reaction Compared with Nasal, Axilla, and Groin and Throat and Perianal Cultures in a Hospital Setting}

To the Editor-Rapid detection of methicillin-resistant Staphylococcus aureus (MRSA) carriage by polymerase chain reaction (PCR) methods and early patient isolation could reduce the chances of nosocomial transmission between patients. ${ }^{1}$ However, the cost of PCR and MRSA prevalence could influence choice of testing method in a hospital screen- 